\title{
The International Finance Corporation's MBA Survey: How Developing Country Firms Rate Local Business School Training
}

\author{
Azam Chaudhry \\ Global Business School Network \\ International Finance Corporation
}

World Bank Policy Research Working Paper 3182, December 2003

The Policy Research Working Paper Series disseminates the findings of work in progress to encourage the exchange of ideas about development issues. An objective of the series is to get the findings out quickly, even if the presentations are less than fully polished. The papers carry the names of the authors and should be cited accordingly. The findings, interpretations, and conclusions expressed in this paper are entirely those of the authors. They do not necessarily represent the view of the World Bank, its Executive Directors, or the countries they represent. Policy Research Working Papers are available online at http://econ.worldbank.org. 


\begin{abstract}
Graduate education in business administration was developed in the U.S. around the turn of the twentieth century. MBA and similar graduate-level business programs took hold more slowly in other countries, but the number of such programs expanded more rapidly from the 1960s onward. In an effort to determine what firms from these countries require from business school graduates, the IFC used its extensive contacts with these firms to conduct a survey of the quality of business education in these countries. The survey results imply that the strengths and weaknesses of developing and transition country MBAs seem to overlap with those of MBAs from the U.S.: managers in the U.S. and in the developing countries find that the technical and analytical skills of MBAs are well developed while the practical training/skills and communication/language skills of MBAs are significantly lacking. On the whole, only the African and Middle Eastern firms were significantly dissatisfied with the quality of local MBA graduates. The survey results show that MBAs worldwide are not fully satisfying the needs of firms. Each of the other regions of the world has its own particular weaknesses, while at the same time some common weaknesses (such as work experience and communication skills) stand out. These results show that a 'cookie-cutter' approach to training MBAs cannot work. Rather, MBA programs have to be tailored to suit the needs of the local business community while also teaching common business fundamentals.
\end{abstract}




\section{Introduction}

Graduate education in business administration was developed in the U.S. around the turn of the twentieth century. The number of Master's in Business Administration (MBA) degrees awarded grew rapidly in the U.S., especially in the second half of the century. MBA and similar graduate-level business programs took hold more slowly in other countries, but the number of such programs expanded more rapidly from the 1960s onward. There is little question that business education and the MBA degree in particular have been instrumental in training better managers and improving the productivity of a wide range of firms. But to date, there has been scarce empirical evidence of the utility of such degrees throughout the world. Rather, much of the emphasis of research has been on the quality and utility of graduate business degrees obtained in the U.S. and Europe. This survey is an attempt to determine the quality of business training and the utility of graduate business degrees in developing and transition countries.

Recently the IFC has developed the Global Business School Network (GBSN) initiative, aimed at improving the training and quality of business managers in developing and transition countries. In an effort to determine what firms from these countries require from business school graduates, the IFC used its extensive contacts with these firms to conduct a survey of the quality of business education in these countries.

The survey was conducted over a period of two months (January - February 2003). More than 1100 surveys were sent to firms by email and fax, and 283 responses were received from 78 countries. The results of the survey are analyzed across various dimensions: across regions, across income categories, across sectors and across firm sizes. It is important to note that the results should be viewed in the light of factors such as response rates across regions and across countries. But keeping in mind these limitations, the results shed light on important and uncharted areas.

The study begins with a discussion of the previous research on the subject in Section II, a description of the survey in Section III, and a discussion on the response rates for the survey in Section IV. Sections V - X present basic analyses of the strengths and weaknesses of local MBA graduates and what factors affect the perceived quality and quantity of MBAs hired by developing and transition country firms. Section XI presents an econometric analysis of the factors affecting the perceived quality of local MBA graduate training. Finally, the conclusions from the survey are presented in Section XII. 


\section{Previous Research}

The background literature on the quality of MBA training has taken two forms. First, there are numerous sources that have rated MBA programs over the past two decades. Second, there are a few analyses and surveys that have examined the quality of MBA graduates in terms of particular skills.

BusinessWeek was the first source to publish a periodic ranking of MBA programs in 1988, to be soon followed by U.S. News and World Report, as well as the Financial Times, Forbes, The Economist, The Wall Street Journal, and America Economia. The initial rankings focused exclusively on U.S. business schools, but in the last decade international schools have also been included in some rankings. While BusinessWeek still focuses most of its attention on schools in North America, Canada and Latin America, the Financial Times and the Economist Intelligence Unit (EIU) now have lists of the top 100 international MBAs, which include universities from North America, Latin America, Europe, and Asia. At the regional level, Asian business schools are ranked yearly by AsiaWeek. At the national level, publications like the Financial Mail of South Africa and Business Today of India rank national business schools, though these rankings only exist for a limited number of countries.

Despite the fact that the MBA rankings now look across the world and are divided into different business fields (with separate rankings for areas such as finance or marketing), the information they provide is comparative across programs and does not reveal firms' views on the quality of MBA graduate training in general. Though it can be argued that the market must value the services of MBAs because firms continue to hire increasing numbers of these graduates at substantial costs, the present rankings system reveals little about the overall quality of MBA training.

The set of material that looks specifically at the quality of MBA graduates' training is far more limited. An interesting article by Pfeffer and Fong (2002), "finds that business schools are not very effective: Neither possessing an MBA degree nor grades earned in courses correlate with career success, results that question the effectiveness of schools in preparing their students". "First, the authors cite studies in which firms found that nonMBAs performed as well as, or better than, their business school counterparts. ${ }^{2}$ The authors also present evidence that the curriculum taught in business schools has a relatively small relationship to what is important for succeeding in business, though it should be noted that the evidence used may be dated. ${ }^{3}$ Similar ideas have been echoed in other recent papers, such as that of Mintzberg and Gosling (2002). ${ }^{4}$ Analysis of information about MBA graduates from outside the U.S. is scarce. Included in this

\footnotetext{
${ }^{1}$ Pfeffer, J. and Fong, C., "The End of Business Schools? Less Success Than Meets the Eye," Journal of Management Learning and Education, 2002,Vol. 1, No. 1, 78-95. See page 78.

${ }^{2}$ Leonhardt, D., "A Matter of Degree? Not for Consultants," New York Times, October 1, 2000, Section 31:1-18. Lieber, R., "Learning and Change: Roger Martin," Fast Company, December 1999, 30:262.

${ }^{3}$ Porter, L. and McKibbin, L., "Management Education and Development: Drift or Thrust into the $21^{\text {st }}$ Century," 1988, New York: McGraw-Hill.

${ }^{4}$ Mintzberg, H. and Gosling, J., "Reality Programming for MBAs," Strategy and Business, 2002, 26 (1): 2831.
} 
limited material is a 1990 analysis of MBA programs in Indonesia, and an analysis of MBA programs in South Africa. ${ }^{5}$

More direct evidence of how employers view MBA graduates is limited. One source of information is an informal survey of senior finance executives by $C F O$ magazine, conducted in $1997 .{ }^{6}$ The results of the survey are illuminating, but limited in scope: The survey found that $60 \%$ of the sample said that new MBA graduates learn too much finance theory and not enough about practical financial management. Also, $70 \%$ of the executives in the survey awarded a " $C$ " or " $D$ " grade to MBA graduates' personal communication skills (out of a scale of A, B, C, D, and F with A being the best and F being the worst). In 1994, James Neelankavil conducted a more formal survey of human resource directors of Fortune 1000 firms about the quality of MBA graduates. ${ }^{7}$ The results of this survey will be discussed in the following sections, and will provide the only source of comparison for this survey's results.

Thus the research and analysis on the quality of MBA training has been quite limited, and the little that exists has looked at MBA training on a more modest scale than this survey has done (in terms of the number of firms surveyed and countries analyzed). In this sense, this work can be viewed as the first cross-country analysis of the quality of MBA graduates.

\footnotetext{
${ }^{5}$ Pesulima, L.S., "Empirical Investigation of the MBA Program in Indonesia: Academic versus Practitioner Perceptions," Nova University, Fort Lauderdale, Florida. Published PhD thesis; and Louw, L., "The Status and Nature of MBA Programmes in South Africa," University of Port Elizabeth. Port Elizabeth: Unpublished D. Com thesis.

${ }^{6}$ Harris, R. and Barr, S., "Incomplete EducationCFO Magazine, April 1, 1997.

${ }^{7}$ Neelankavil, J., "Corporate America's Quest for an Ideal MBAJournal of Management Development, 1994, Vol. 13, No. 5, page 38-52.
} 


\section{The Survey}

The survey was sent to IFC client firms in developing and transition countries, and asked both firm-specific questions and questions about the perceived quality of the locally trained MBAs hired by the firms. In the survey, the term 'local MBA' was applied to individuals with graduate business administration degrees from schools within the country in which the firm was located. The survey also specified that local graduate degrees in business administration may not be called 'MBAs' and the firm should rate the equivalent local degree. The survey itself is attached in Annex A.

The firm-specific information included the name of the firm, the sector in which the firm operates (obtained from IFC databases), the size of the firm based on number of employees, and the average number of local MBAs the firms hire each year. If firms responded that they do not hire MBAs, they were asked to explain why they did not.

The questions pertaining to the perceived quality of locally trained MBAs began with questions about the technical, communication and language skills of locally trained MBAs. Respondents were asked to rate locally trained MBAs on the following scale: (1) Lacking, (2) Inadequate, (3) Adequate, (4) Good and (5) Not Applicable. These questions were followed by open-ended questions on the perceived strengths and weaknesses of local MBAs. The final question about the quality of local MBA graduates asked for an overall evaluation of local MBA graduates, and answers were chosen from the scale: (1) MBAs are inadequately prepared, (2) MBAs are fairly well prepared, (3) MBAs are well prepared, and (4) Not Applicable.

The survey also asked from which local schools the firms usually hired MBAs, and which schools produce the best MBAs in the country. Usually, the firms mentioned the same schools for both questions.

The firm-specific information was used to classify opinions about the quality of local MBA graduates based on firm size, sector and number of MBAs hired each year. Such categorization of responding firm information was done to determine whether these factors are correlated with responses regarding MBA quality. In the sections that follow, the main results are discussed. 


\section{Rates of Response}

Table 1: Regional Breakdown of Survey Responses

\begin{tabular}{|lccc|}
\hline \multicolumn{1}{|c|}{ Region } & $\begin{array}{c}\text { Number of Surveys } \\
\text { Sent to Region }\end{array}$ & Number of Responses & \% Response \\
\hline AFRICA & 218 & 39 & 18 \\
\hline EAST ASIA & 134 & 38 & 28 \\
\hline $\begin{array}{l}\text { LATIN } \\
\text { AMERICA }\end{array}$ & 289 & 70 & 24 \\
\hline $\begin{array}{l}\text { MIDDLE } \\
\text { EAST }\end{array}$ & 74 & 24 & 32 \\
\hline SOUTH ASIA & 135 & 24 & 18 \\
\hline EUROPE & 273 & 88 & 32 \\
\hline TOTAL & 1123 & 283 & 25 \\
\hline
\end{tabular}

As with any survey, the first question to be asked is: What was the response rate? In the case of this survey, Table 1 shows that the overall response rate was $25 \%$, with 283 surveys received from 78 countries. ${ }^{8}$ This response rate is relatively high for an international survey of this breadth. An interesting point of comparison is the lower response rate of a survey of Fortune 1000 companies conducted in 1994 by James Neelankavil. ${ }^{9} \quad$ In order to evaluate how American firms viewed MBA programs, Neelankavil sent out a questionnaire to 1000 human resource directors of Fortune 1000 firms and received 108 responses, implying a response rate of $10.8 \%$, which is significantly lower than the response rate of this survey. The high response rate is a result of the fact that the surveyed firms are IFC clients, which means that they belong to a specific subset of firms with strong international relationships. Therefore, the sample of firms in the survey is not fully representative of all firms in developing countries, and the results may be slightly biased.

The regional breakdown of firms is based on the World Bank classification system: (1) Africa (excluding the North African countries), (2) East Asia, (3) Latin America and the Caribbean, (3) Middle East and North Africa, (4) South Asia, and (5) Europe. Though Europe can be divided further into Eastern and Western Europe, most of the European responses were from Eastern European countries (see Annex B) and thus the general heading of Europe was used to classify responses from that region

Table 1 also shows that the regional response rates are uniformly high, ranging from 17\% for the African region to $32 \%$ for the European region. Even though it is clear that conclusions from the survey for each region are also dependent on the distribution of

\footnotetext{
${ }^{8}$ See Annex B for the list of countries, and number of responses from each country.

${ }^{9}$ Neelankavil, J., “Corporate America's Quest for an Ideal MBA," Journal of Management Development, Vol. 13 No. 5, 1994.
} 
countries within each region that sent responses, one can still draw some interesting conclusions.

The other categories of respondents were based on the income category of the country in which the firm is located (Table 2), the sector in which the firm operates (Table 3), the size of the firm in terms of number of employees (Table 4), and the number of MBAs the firm hires yearly (Table 5). As the tables below show, the sample of responding firms is distributed quite evenly, with the only exception being the large proportion of firms that fall into the Finance and Insurance sector.

Table 2: Breakdown by Income Category of Country ${ }^{10}$

\begin{tabular}{|c|c|c|}
\hline $\begin{array}{c}\text { Income Category } \\
\text { of Country }\end{array}$ & $\begin{array}{c}\text { Number of } \\
\text { Respondents }\end{array}$ & Percentage \\
\hline I & 82 & $29 \%$ \\
\hline II & 36 & $13 \%$ \\
\hline III & 85 & $30 \%$ \\
\hline IV & 43 & $15 \%$ \\
\hline V & 25 & $9 \%$ \\
\hline Not Available & 12 & $4 \%$ \\
\hline Total & 283 & $100 \%$ \\
\hline
\end{tabular}

Table 3: Breakdown by Sector of Firm

\begin{tabular}{|l|c|c|}
\hline Sector & $\begin{array}{c}\text { Number of } \\
\text { Respondents }\end{array}$ & Percentage \\
\hline Finance \& Insurance & 121 & $43 \%$ \\
\hline Food \& Agribusiness & 27 & $10 \%$ \\
\hline $\begin{array}{l}\text { Industrial/Consumer } \\
\text { Products, } \\
\text { Health/Education, } \\
\text { Utilities \& Technology }\end{array}$ & 63 & $22 \%$ \\
\hline $\begin{array}{l}\text { Metallic and } \\
\text { Nonmetallic Mineral } \\
\text { Products }\end{array}$ & 24 & $8 \%$ \\
\hline Oil, Gas \& Chemicals & 24 & $8 \%$ \\
\hline $\begin{array}{l}\text { Transportation, } \\
\text { Warehousing \& Retail } \\
\text { Trade }\end{array}$ & 24 & $8 \%$ \\
\hline Total & 283 & $100 \%$ \\
\hline
\end{tabular}

\footnotetext{
${ }^{10}$ World Bank income categories are based on the per capita incomes of countries. The range of the income categories is I-V, with I being the lowest and V being the highest: Countries in Category I have a per capita income of $\$ 746$ or less; those in Category II, between $\$ 746$ and $\$ 1435$; Category III, between $\$ 1436$ and \$2975; Category IV, between \$2976 and \$5185; Category V, over \$5185.

${ }^{11}$ Information is unavailable because the firm is part of a regional conglomerate and did not specify country.
} 
Table 4: Breakdown by Size of Firm

\begin{tabular}{|l|c|c|}
\hline $\begin{array}{c}\text { Size of Firm (Number of } \\
\text { Employees) }\end{array}$ & $\begin{array}{c}\text { Number of } \\
\text { Respondents }\end{array}$ & Percentage \\
\hline $0-100$ & 66 & $22 \%$ \\
\hline $101-500$ & 79 & $28 \%$ \\
\hline $501-2000$ & 64 & $23 \%$ \\
\hline$>2000$ & 53 & $19 \%$ \\
\hline Not Available & 21 & $8 \%$ \\
\hline Total & 283 & $100 \%$ \\
\hline
\end{tabular}

Table 5: Breakdown by Number of MBAs Hired Each Year

\begin{tabular}{|c|c|c|}
\hline $\begin{array}{c}\text { Number of MBAs hired } \\
\text { each year }\end{array}$ & $\begin{array}{c}\text { Number of } \\
\text { Respondents }\end{array}$ & Percentage \\
\hline 0 & 96 & $34 \%$ \\
\hline $1-2$ & 91 & $32 \%$ \\
\hline $3-10$ & 60 & $21 \%$ \\
\hline$>10$ & 24 & $9 \%$ \\
\hline Not Available & 12 & $4 \%$ \\
\hline Total & 283 & $100 \%$ \\
\hline
\end{tabular}

A final point should be noted about the response rate. There are numerous reasons why a firm may not have responded to the questionnaire. Some of the reasons that a firm did not respond may include: the firm did not receive the survey (because of incorrect or outdated contact information), or the firm does not hire MBAs. The second of the reasons given above is extremely important because it could imply that firms do not hire MBAs because they do not find them to be of sufficient quality, because they cannot afford them, or because they are just not available. Factors like these should be kept in mind when analyzing the results of the survey. 


\section{Why Don't Firms Hire MBAs?}

Of the 277 responses, 113 of the firms said that they hire no MBAs. This is important not just because it shows that a significant number of the respondents did not hire MBAs, but also because we can categorize the reasons for this decision.

\section{Figure 1}

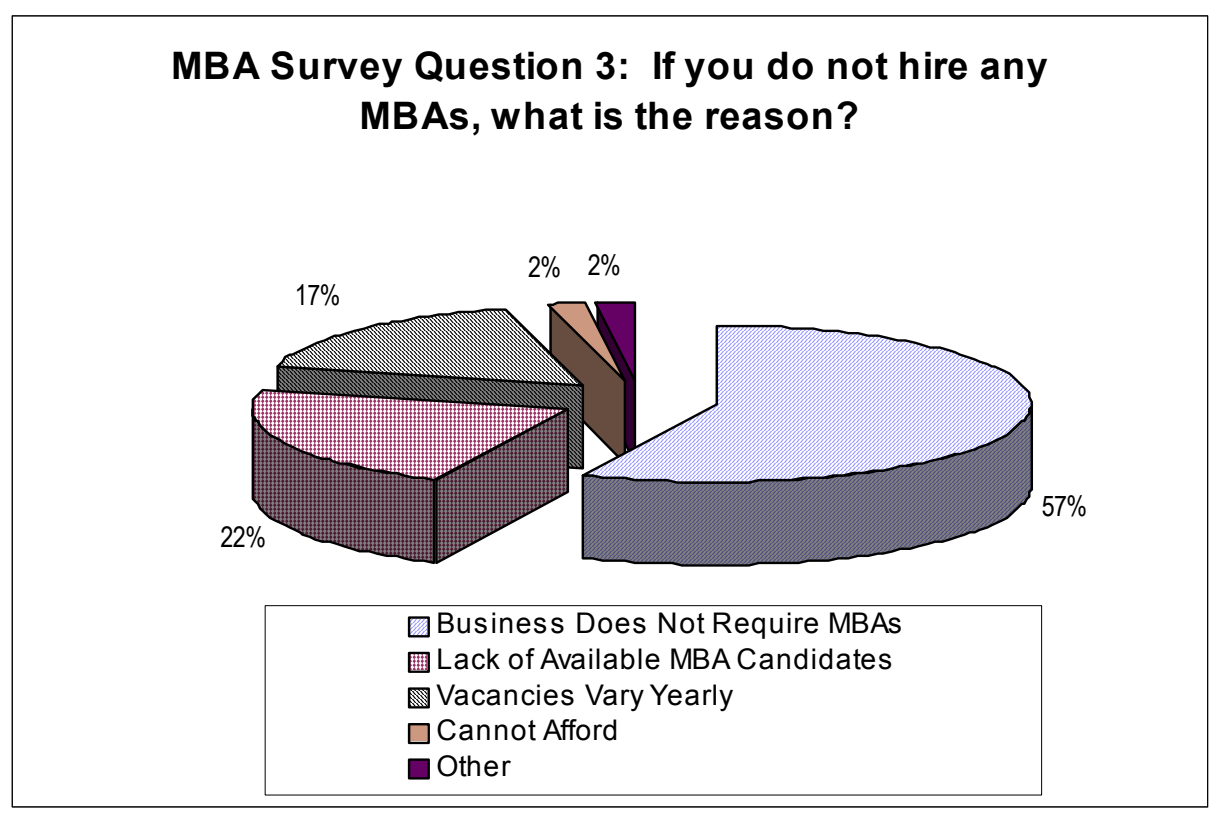

Figure 1 shows some of the reasons firms gave for not hiring MBAs. First, note that 57\% of the firms said that they did not hire MBAs because their businesses did not require MBAs. But this sub-sample can be broken down further. There were 65 firms that responded that they do not hire MBAs because their businesses did not require them. Of these 65 firms, 22 firms said that they trained their own employees or sent their employees to part-time MBA programs. Thirty-six firms said that the nature of their businesses was such that they did not require MBA graduates (such as glass manufacturing), and seven said that they were actually in the process of restructuring or downsizing.

It may be useful to look at the regional breakdown of the 22 firms that reported that they trained their own employees. Of these 22 firms that trained their own employees, eight were from Latin America, and the remaining 14 were evenly distributed among the other regions (with about three each). Though there were significantly more responses from Latin America than from other regions, it is interesting to note that firms in Latin America seem to rely on in-house training more than firms in the other regions.

The second important issue to analyze is the fact that $22 \%$ of the firms surveyed said that they did not hire MBAs because of a lack of available candidates. At the regional level, $56 \%$ of Middle Eastern respondents said that they did not find available candidates, while $32 \%$ of African firms gave the same response. 
It is useful to analyze the issue of why firms said that MBAs were unavailable. Of the 25 firms that said that MBAs were unavailable, five said that MBAs with specific skills needed in their sector were unavailable, while 19 said that there were just too few local MBAs. Of these 19, five respondents were from Africa, and five were from the Middle East. This means that five out of 36 African respondents (14\%) reported a shortage of MBA graduates; and five out of 23 Middle Eastern respondents (22\%) found the same shortage. Though the sample size is quite limited, this could be an indication of a shortage not only of good programs, but of programs in general in these two regions.

By World Bank income category, 29\% of respondents from Category I countries said that they did not hire MBAs because of a lack of availability. ${ }^{12}$ This figure is significantly higher than the corresponding figure for other income categories, and implies that countries from the lowest income category have a significant shortage of qualified MBAs.

The previous research in this area is limited to the discussion in Pfeffer and Fong (2002), which focused only on the U.S. In their paper, Pfeffer and Fong found that consulting firms (such as Booz Allen and Hamilton and Boston Consulting Group) hired a significant number of non-MBAs, who learned the fundamentals of business after a few weeks of training (pg. 81). But there has been very little research on why firms would not want to hire MBAs.

\footnotetext{
${ }^{12}$ World Bank income categories are based on the per capita incomes of countries. The range of the income categories is $\mathrm{I}-\mathrm{V}$, with I being the lowest and $\mathrm{V}$ being the highest: Countries in Category I have a per capita income of $\$ 746$ or less; those in Category II, between $\$ 746$ and $\$ 1435$; Category III, between \$1436 and \$2975; Category IV, between \$2976 and \$5185; Category V, over \$5185.
} 


\section{How Did the Firms Rate the Technical Skills of Locally Educated MBAs?}

\section{Figure 2}

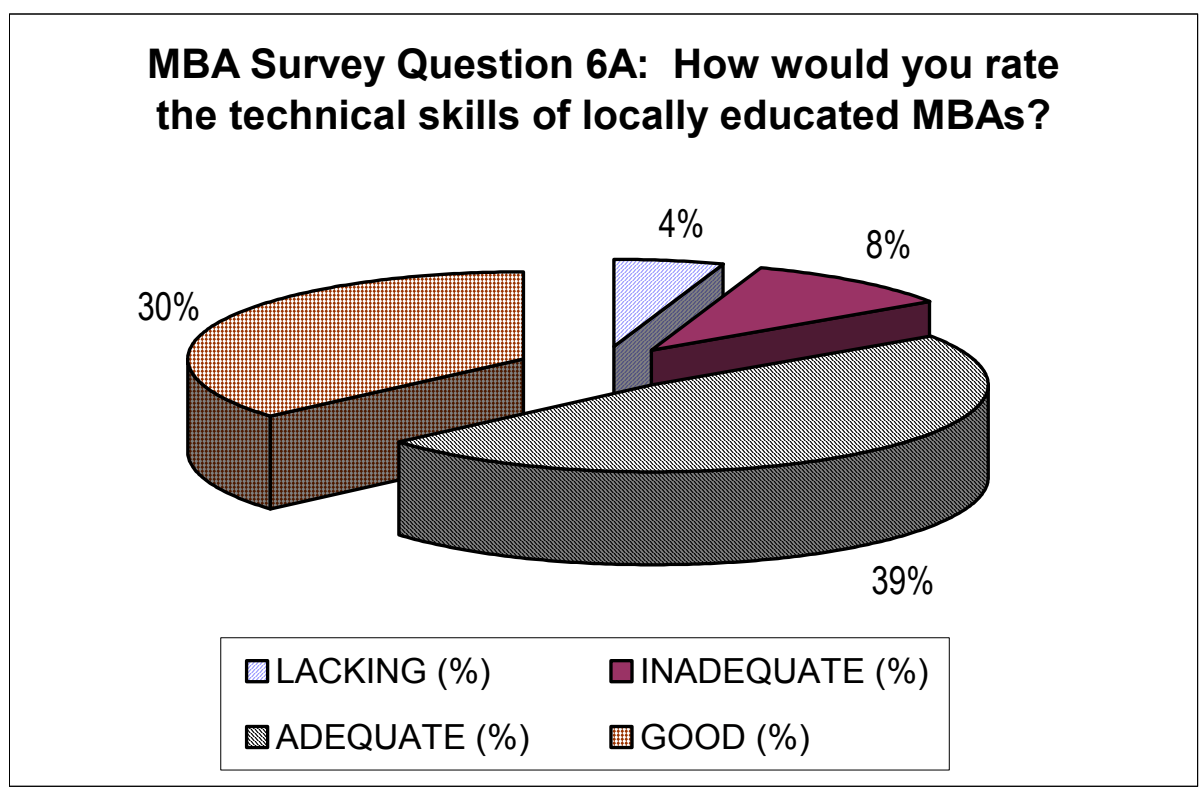

As Figure 2 shows, 69\% of the survey respondents found the technical skills of the locally trained MBAs to be either adequate or good.

At the regional level, three regions stand out. First, 25\% of respondents in Africa found the technical skills of business graduates to be lacking or inadequate. Considering the fact that for the entire survey sample of firms only $12 \%$ of the firms found the technical skills of business graduates lacking or inadequate, the African statistics imply a particular problem in the quality of technical training of African business school graduates. The other cases that are noteworthy are the South Asian results, in which $21 \%$ of the respondents were dissatisfied with the quality of technical training, and the Middle Eastern results in which $17 \%$ of respondents found the quality of technical skills inadequate.

On the other end of the scale, firms from East Asia, Europe and Latin America were satisfied with the quality of technical training imparted by local business schools. Specifically, $72 \%$ of the East Asian respondents, $70 \%$ of the European respondents and $80 \%$ of the Latin American respondents rated the technical training of local MBA graduates to be either adequate or good.

An analysis of the responses across World Bank income categories demonstrates that the countries making up Category I (the lowest income category) are the least satisfied with the technical skills of local MBAs: $20 \%$ of responding firms from Category I found the technical skills of locally educated MBAs to be lacking or inadequate, more than those of 
any other income category. ${ }^{13}$ The question of technical skills will be further investigated in the discussion of Questions 7 and 8, where the strengths and weaknesses of locally educated MBAs are evaluated.

The previous work done on rating the technical skills of MBAs is limited in both quantity and scope. The only well-known examples are the CFO survey (1997) and the Neelankavil survey (1994), and both looked primarily at graduates from U.S. business schools. The CFO survey found that $60 \%$ of the finance executives surveyed said that newly minted MBAs were well acquainted with finance theory. Neelankavil found that most of the executives he surveyed found that MBA programs focus on technical skills and that overall, the MBAs coming into the market were technically well prepared. ${ }^{14}$

These results imply that both U.S. MBA programs and international MBA programs place heavy emphasis on imparting technical skills to their graduates. An interesting question is whether the developing and transition countries have simply followed the lead of U.S. business programs, or whether MBA programs are responding to a perceived demand for strong technical skills.

\footnotetext{
${ }^{13}$ Countries in Category I have a per capita income of $\$ 746$ or less.

${ }^{14}$ Neelankavil, J., "Corporate America's Quest for an Ideal MBA," Journal of Management Development, Volume 13 No. 5, 1994. See page 40. Note that Neelankavil does not present any specific statistics about this conclusion.
} 


\section{How Did the Firms Rate the Interpersonal and Communication Skills of Locally Educated MBAs?}

Figure 3

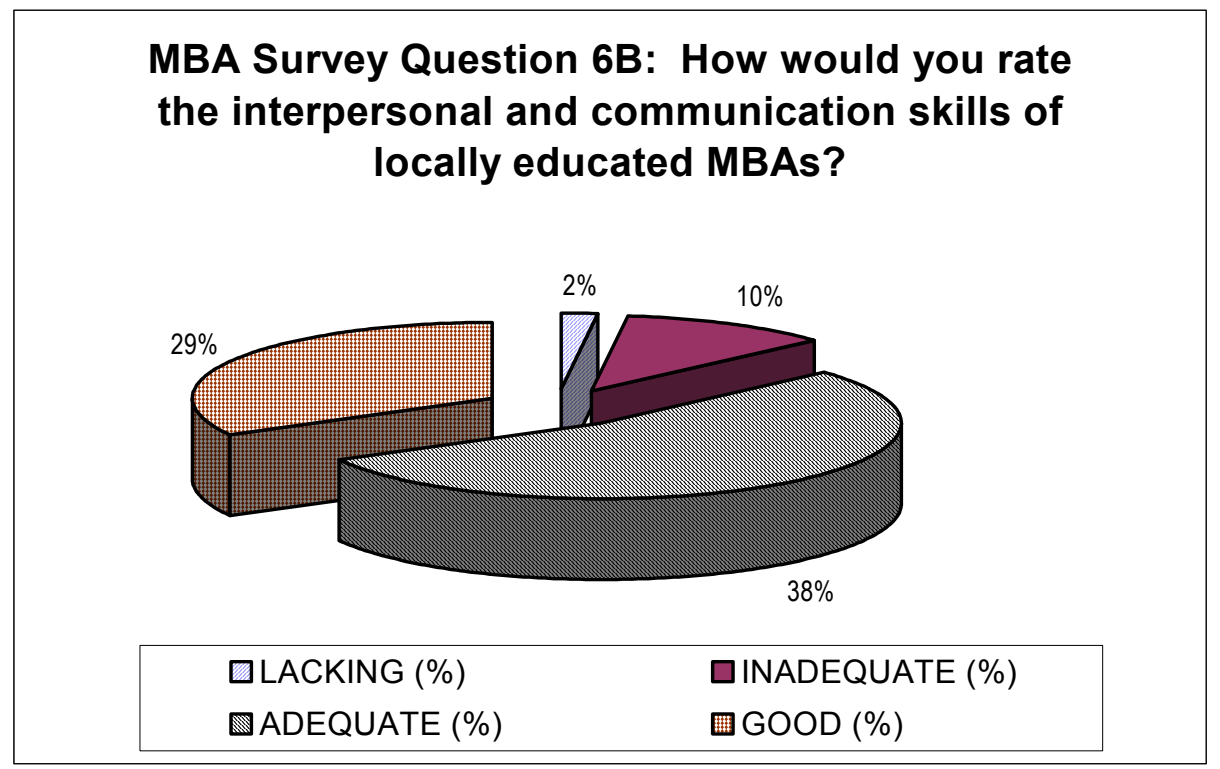

As with the discussion of MBA training in technical skills above, respondents found that locally trained MBAs were acceptable in their interpersonal and communication skills. As shown in Figure 3,67\% of respondents found the interpersonal and communication skills of locally educated MBAs to be either adequate or good, with $38 \%$ saying that skills were adequate and $29 \%$ saying that they were good. Only $12 \%$ found that the interpersonal and communication skills of local MBAs were lacking or inadequate.

An analysis across regions demonstrates that the only standout is the Middle Eastern region, in which $26 \%$ of the respondents were dissatisfied with the level of interpersonal and communications skills (with a rating of either Lacking or Inadequate), which is significantly higher than the results of the other regions. This may imply a need to focus on the issue of developing interpersonal and communication skills in MBA and similar programs in the Middle Eastern region. On the other hand, more than $60 \%$ of the firms in each of the other regions rated the interpersonal and communication skills of local MBA graduates as either adequate or good.

Across World Bank income categories, the firms display a uniform level of satisfaction with the interpersonal and communications skills of locally trained MBAs. ${ }^{15}$ There is a strong indication that locally trained MBAs (in areas where they are in sufficient numbers) are being satisfactorily trained in the area of communication.

\footnotetext{
${ }^{15}$ World Bank income categories are based on the per capita incomes of countries. The range of the income categories is I-V, with I being the lowest and V being the highest: Countries in Category I have a per capita income of $\$ 746$ or less; those in Category II, between $\$ 746$ and $\$ 1435$; Category III, between $\$ 1436$ and \$2975; Category IV, between \$2976 and \$5185; Category V, over \$5185.
} 
Previous results provide a different story for U.S. MBA graduates. The CFO survey found that $70 \%$ of the executives surveyed assigned a grade of "C" or " $\mathrm{D}$ " (on a scale of A-F, with $A$ being the best and $F$ being the worst). This is a far higher level of dissatisfaction with the communication and interpersonal skills of MBA graduates than found in the IFC MBA survey. Neelankavil found that business executives thought that most MBA graduates lacked communication skills and were very unprepared in the area of written communication.

A comparison of results from this survey with other research shows that firms in developing and transition countries were far more satisfied with the quality of MBA communication skills from their local business schools, than were U.S. firms with the communication skills of graduates from U.S. business schools. But it is important to point out that this does not mean that the MBA graduates have better communication skills abroad; rather it simply means that developing country firms are more satisfied with the communication skills of their local graduates, and programs aimed at improving the quality of business skills in these countries should focus less on training in the area of communication and interpersonal skills and more on other priority areas. 


\section{How Did the Firms Rate the Fluency in International Languages of Locally Educated MBAs?}

Figure 4

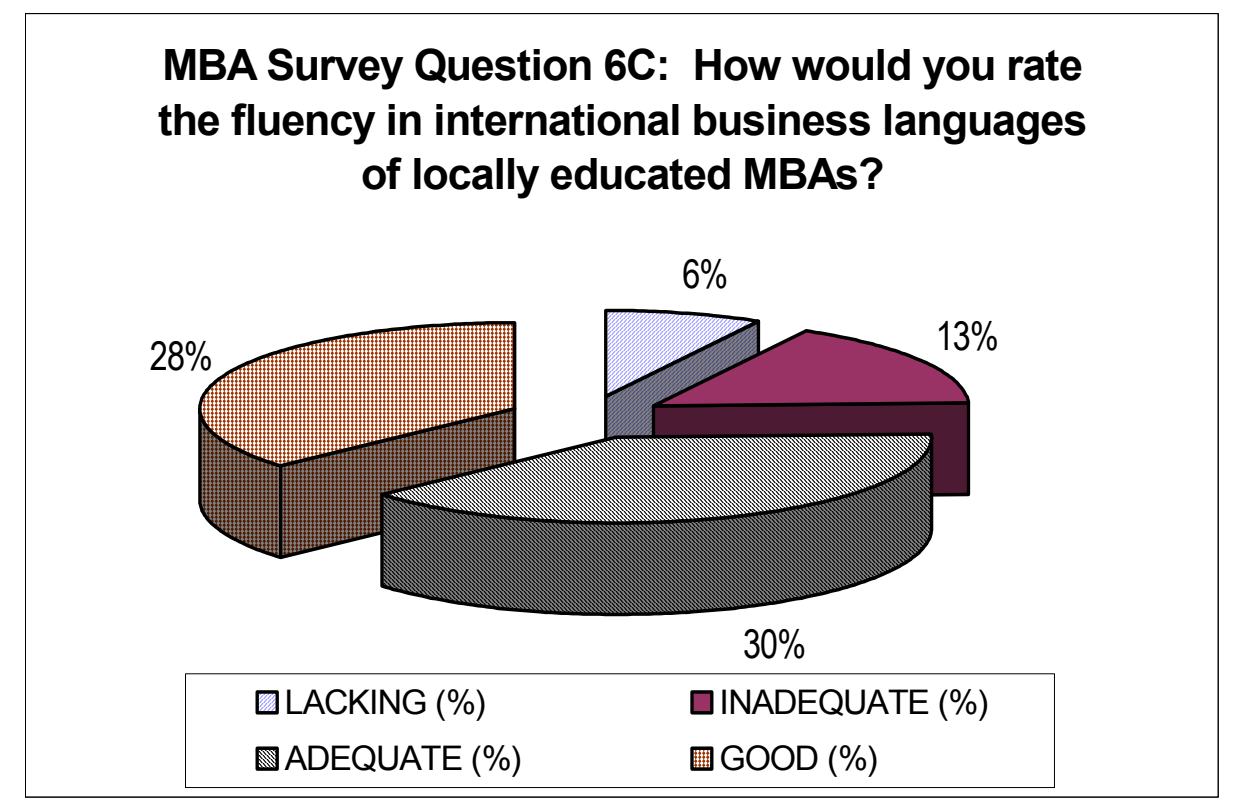

Figure 4 shows that unlike the areas discussed above, 19\% of the responding firms found the language skills of locally trained MBAs to be either lacking or inadequate, while 58\% of respondents found the language skills of locally trained MBAs to be adequate or good. Comparing the statistics for technical training and communication skills, there is a greater proportion of respondents who were dissatisfied with the language skills of local business graduates, than the proportion of respondents who were dissatisfied with the other skill areas.

At the regional level, two regions stand out: $36 \%$ of East Asian respondents and $30 \%$ of Latin American respondents were dissatisfied with the language skills of local MBA graduates (with a rating of lacking or inadequate). The dissatisfied responses from other regions were significantly lower. Considering the level of business ties that Latin America and East Asia have with the industrialized countries, such a response is a strong indication of the need to concentrate on developing the skills of local MBAs in international business languages.

By contrast, firms in the other regions found the fluency in international business languages of the local MBAs to be satisfactory. $63 \%$ of the firms responding from Europe, $69 \%$ of the firms responding from the Middle East, and $71 \%$ of the firms responding from South Asia rated the fluency of local MBAs in international business languages to be either adequate or good. 
These results are in contrast to the results obtained by looking at countries grouped by World Bank income categories. ${ }^{16}$ In this case, there is uniformity in the level of satisfaction with the language skills of local MBAs. The interesting exception is that $32 \%$ of respondents from Income Category $\mathrm{V}$ (the category with the highest income levels) found the language skills of local MBAs to be lacking or inadequate. This is due mainly to the dissatisfaction with these skills expressed by the East Asian and Latin American respondents.

The analysis of international language skills of MBA graduates has been completely ignored in previous analyses, which may imply that U.S. businesses are less concerned with this issue than international businesses, or that U.S. MBA programs do not consider this a necessary priority. But the evidence above shows that international businesses are very concerned with the issue, and programs that focus on business education in the developing and transition countries should include training in international business languages.

\footnotetext{
${ }^{16}$ World Bank income categories are based on the per capita incomes of countries. The range of the income categories is I-V, with I being the lowest and V being the highest: Countries in Category I have a per capita income of $\$ 746$ or less; those in Category II, between $\$ 746$ and $\$ 1435$; Category III, between $\$ 1436$ and \$2975; Category IV, between \$2976 and \$5185; Category V, over \$5185.
} 


\section{What are the Strengths and Weaknesses of Locally Educated MBAs?}

One of the most important questions in the survey was the question of what firms perceived to be the strengths and weaknesses of locally trained MBAs. The results are given in the figures below.

Figure 5

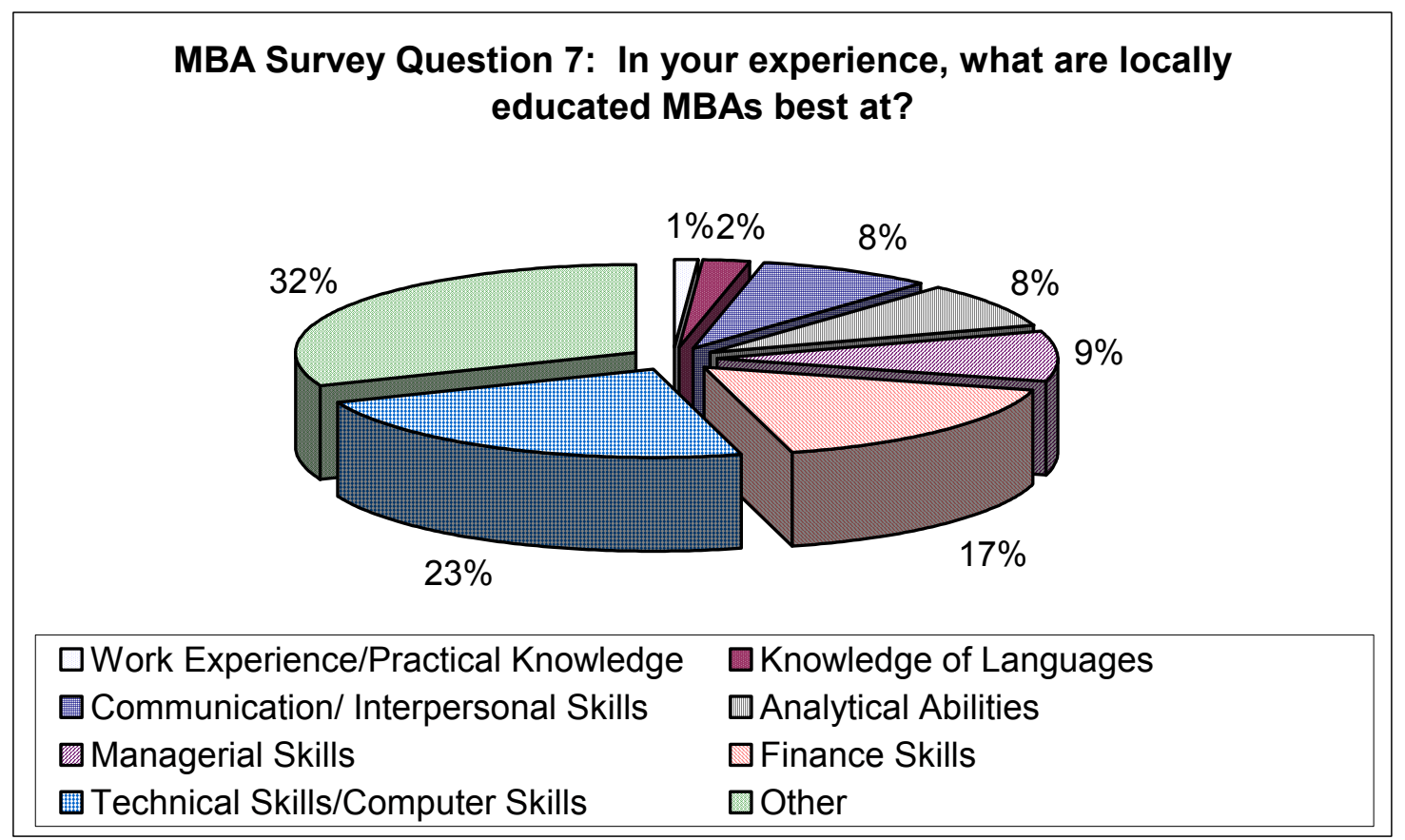

Question 7 of the survey asked about the greatest strength of local MBA graduates. Since the question was left open, a myriad of responses was received, though the most important responses can be separated from the rest. As Figure 5 shows, the majority of respondents $(23 \%)$ found the technical skills of locally trained MBAs to be their greatest strength. The category of 'Other' encompasses about eight more subcategories, with no particular sub-category standing out. The second strength cited most frequently concerned financial skills, which was identified by $17 \%$ of the respondents. Other significant strengths were managerial skills, analytical abilities, and communication skills.

Across all regions, the skills found to be the strongest among local MBAs were the analytical/technical skills. The only exception is the African region where the strongest skill identified was communication and language skills (the analytical and technical skills were found to be significantly weaker in this region than in other regions). The survey found that $30 \%$ of the African respondents found these skills to be the strongest asset of local MBAs, which is higher than the corresponding responses from the other regions. Only 13\% of African respondents found the analytical/technical skills of local MBAs to be their strongest asset, which is lower than the corresponding responses from the other regions. 
Across World Bank income categories, the responses are fairly consistent: respondents found the analytical and technical skills of the local MBAs to be their strongest asset. Here, an interesting result reflects a discussion in a previous section: for higher income categories, a smaller percentage of firms find the communication/language skills to be the local MBAs' strongest asset.

Neelankavil also looked at the strengths of MBA graduates from U.S. business schools (as perceived by Fortune 1000 executives) and found that their main strengths were technical skills, computer skills, oral communication and strategic planning. So, both Neelankavil's results and the IFC MBA survey results show that the greatest strength of new MBAs is their technical and computer skills.

What this seemingly indicates is an emphasis in both Western country and developing country MBA curricula on imparting technical skills and teaching finance. This is particularly useful since any program to assist developing country business schools could build upon the technical training already in place in the developing and transition countries.

\section{Figure 6}

\section{MBA Survey Question 8: In your experience, what do locally educated MBAs lack most?}

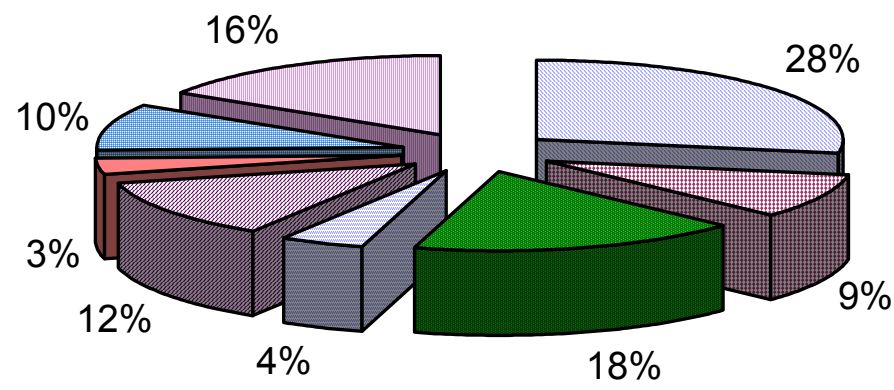
$\square$ Work Experience/Practical Knowledge
$\square$ Communication/ Interpersonal Skills
$\square$ Managerial Skills
$\square$ Analytical Abilities
$\square$ Technical Skills/Computer Skills
$\square$ Finance Skills
口Other

Knowledge of Languages

The perceived weaknesses of locally trained MBAs are particularly interesting. Figure 6 shows that $28 \%$ of the responding firms found that MBAs lacked sufficient work experience and practical knowledge. This result is common across regions and across income categories, which implies a need for greater work experience and practical training, through pre-MBA work experience, internships, and real world case studies, in developing country business programs. Many of the firms specifically pointed this out to be a weakness caused by lack of work experience before and during MBA programs. 
Another major weakness highlighted by responding firms concerns language and communication skills of local MBAs. The survey found that $27 \%$ of the respondents identify this as the greatest weakness of local MBAs (though most of this finding is due to the negative perception of these skill types by Latin American and East Asian firms).

The breakdown of results by World Bank income categories shows that across all income groups, firms consistently reported that the greatest weakness is the level of practical work experience of local MBAs. ${ }^{17}$

Another interesting point is that $18 \%$ of responding firms stated that the greatest weakness of local MBAs is their inability to communicate or interact with others. This implies that communication and interaction skills are significant weaknesses of developing and transition country MBAs (even though this goes against the results demonstrated in Question 6B above).

In terms of weaknesses, both the CFO survey and Neelankavil's survey provide information on the quality of U.S. MBA graduates. The CFO survey found that $60 \%$ of new MBA graduates learn too much finance theory and not enough about practical financial management. In addition, $70 \%$ of the executives responding to the CFO survey were dissatisfied with the personal communication skills of MBA graduates. In his survey, Neelankavil found that executives thought that U.S. business schools emphasized financial and analytical skills over knowledge of manufacturing processes, and that the greatest weaknesses of MBAs were their ability to handle global challenges, their understanding of the importance of quality, and their written communication skills.

The strengths and weaknesses found in the IFC survey broadly agree with the results found in the two surveys of U.S. firms regarding the quality of U.S. MBAs: The MBA graduates are very well prepared in terms of technical and analytical skills, but they lack a working understanding of international business (because of a lack of practical work experience and real world training), and certain communication skills.

\footnotetext{
${ }^{17}$ World Bank income categories are based on the per capita incomes of countries. The range of the income categories is I-V, with I being the lowest and V being the highest: Countries in Category I have a per capita income of $\$ 746$ or less; those in Category II, between $\$ 746$ and $\$ 1435$; Category III, between \$1436 and \$2975; Category IV, between \$2976 and \$5185; Category V, over \$5185.
} 


\section{Overall Evaluation of Local MBA Programs}

Figure 7

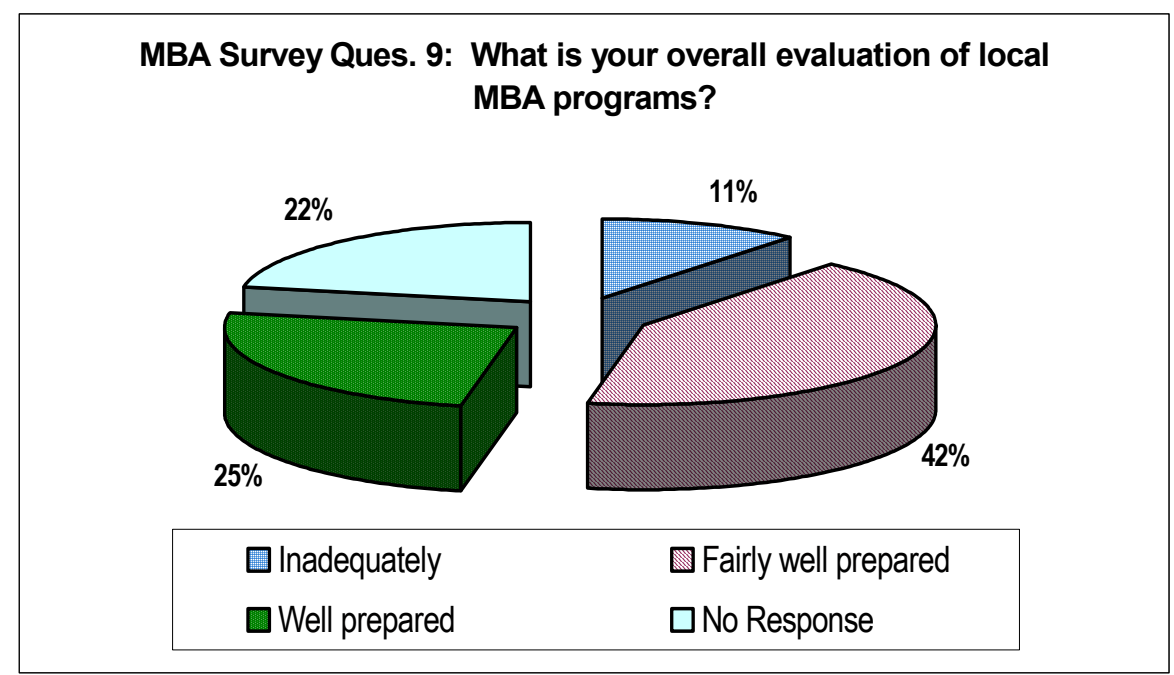

Figure 8

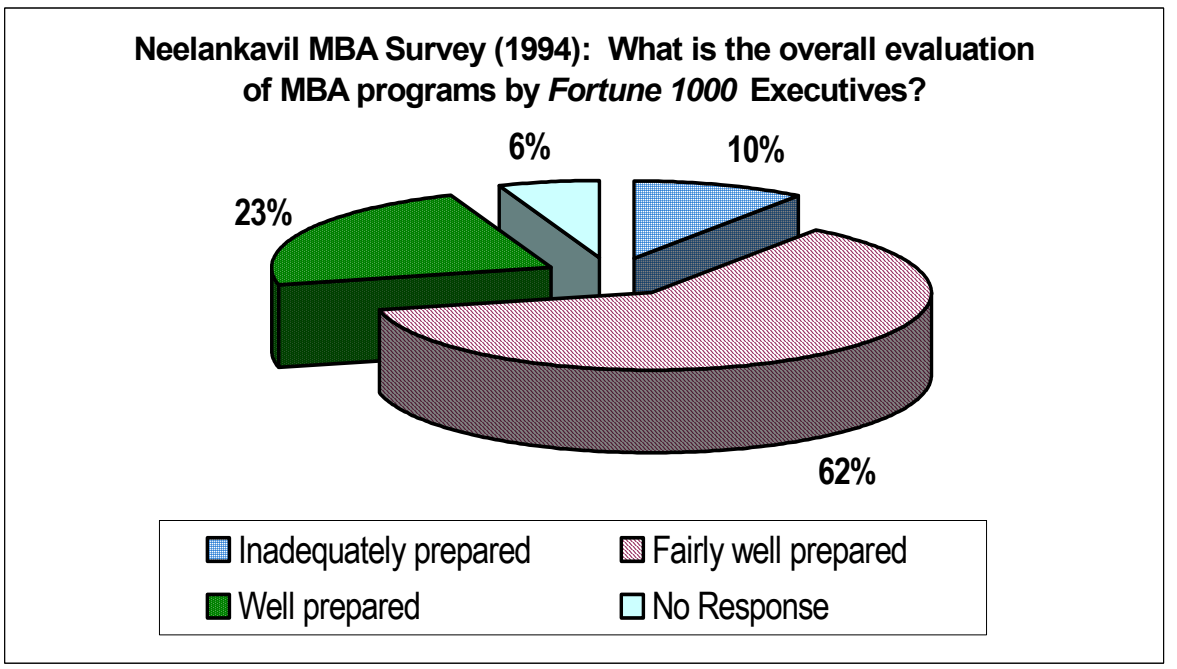

As illustrated in Figure 7, the overall evaluation of emerging market MBA programs shows that $67 \%$ of the respondents find local MBA graduates to be "fairly well prepared" or "well prepared", while $11 \%$ found them to be "inadequately prepared". On the face of it, it seems that businesses judge the overall quality of local MBA graduates to be adequate, though not overwhelmingly strong.

This picture changes, however, at the regional level. In the Africa region, $22 \%$ of respondents said that locally trained MBAs were inadequately prepared, while $17 \%$ of the respondents from the Middle East region also found the local MBAs inadequately prepared. These results seemingly point to a mismatch in the skills imparted to MBA 
graduates in these regions with the skills required by local firms. On the opposite end of the spectrum, 33\% of Latin American firms surveyed found local MBAs to be well prepared, while $31 \%$ of European firms found local MBAs to be well prepared, with the corresponding percentages in the other regions being significantly lower.

Looking at the results across World Bank income categories, firms from income categories I and II were the least satisfied with the quality of local MBA graduates. ${ }^{18}$ Fourteen percent of the firms from category I countries, and $14 \%$ of the firms from category II countries found local MBAs to be inadequately prepared (with the percentages in the other income categories all falling under 10\%). This implies that local MBAs from the countries with the lowest incomes are failing to satisfy the needs of local businesses, and any efforts to improve the quality of business management should begin in this countries.

When comparing the IFC survey results concerning satisfaction of firms with local MBA graduates in emerging markets to Neelankavil's study of American-trained MBAs, one finds similar results. As shown in Figure 8, 23\% of respondents stated that MBAs were "well prepared", $62 \%$ stated that they were "fairly well prepared", and $10 \%$ stated that they were "inadequately prepared". The problems that are perceived by developing country firms about MBA graduates are the same problems cited by U.S. firms.

\footnotetext{
${ }^{18}$ World Bank income categories are based on the per capita incomes of countries. The range of the income categories is I-V, with I being the lowest and V being the highest: Countries in Category I have a per capita income of $\$ 746$ or less; those in Category II, between $\$ 746$ and $\$ 1435$; Category III, between $\$ 1436$ and \$2975; Category IV, between \$2976 and \$5185; Category V, over \$5185.
} 


\section{Econometric Analysis of Local MBA Programs}

\section{A. Introduction}

The MBA survey data can be used to perform numerous econometric analyses in order to determine what factors affect firm-level opinions of local MBA quality. Following the discussion in the previous sections, this statistical analysis is based on country-specific and firm-specific variables.

At the firm level, four significant pieces of information are available: Size of the firm, average number of MBAs the firms hires on a yearly basis, sector of firm, and type of MBA graduates the firm requires (either graduates with general management skills or specific areas of expertise such as finance).

At the country level, various factors can be taken into consideration: GDP per capita in the country, the number of commercial and business administration students in the country (and other measures of availability of education), region, and size of country (in terms of population).

The question arises: How does each of these factors relate to the quality of MBA graduates in each country? At the firm level, it is hypothesized that the size of the firm and the number of MBA graduates it hires each have an effect on the firm's impression of the quality of MBAs. Similarly, the sector of the firm and the type of MBA graduate it hires should also affect the firm's impression of the quality of local MBAs. More specifically, larger firms can generally offer higher salaries and thus attract better MBA graduates. Also, firms that hire more MBAs have a superior pool of MBAs from which to hire than firms that hire fewer MBAs (though it should be noted that there is very little correlation in the data between the size of the firm and the number of MBAs they hire each year). Similarly, firms in different sectors may attract different qualities of MBAs, while firms with different needs also attract different qualities of MBAs.

At the country level, it is hypothesized that countries with higher per capita incomes, higher literacy rates, and greater numbers of business graduates should provide MBAs that are more satisfactory to hiring firms. Besides country-specific effects, it is useful to look at regional effects to see if they explain differences in perceived MBA quality.

Thus the equations estimated take the following form:

Quality of MBA students $=\mathbf{F}$ (Size of firm, Number of MBA graduates they hire, Sector of firm, Type of skills required, Country specific factors, Regional Dummy Variables)

Four different relationships will be investigated: (1) Determination of the technical skills of MBA students, (2) Determination of the communication skills of MBA students, (3) Determination of the language skills of MBA students, and (4) Determination of the overall quality of MBA students. 


\section{B. Data and Variables}

The firm-level data is taken from the survey responses and IFC databases. In particular, the firm's size (in terms of the number of employees), the average number of MBAs hired each year, the type of MBA graduates the firm requires (either General Management or Specific Expertise), and the ratings of MBA students (in the areas of technical skills, communications skills, language skills, and overall) were obtained from the survey. The information on the sector of each firm was taken from the IFC "Edocs" database which contains specific project documents with information about firms and projects.

The country-level data is taken from the Unified Survey Database (taken from the most recent Bank-wide survey on economic data) and the UNESCO Education Database.

Dummy variables were created for each region. The base region (when all the regional dummy variables equal zero) for the regional dummies was Europe, and thus all the other regional dummy results are in comparison to the quality of European MBA students. At this point it should be noted again that the firms that responded from the European region were located in Eastern Europe and Central Asia. Regional dummies were created for Africa, East Asia, Latin America and the Caribbean, the Middle East, and South Asia.

The sectoral analysis also used dummy variables. In particular, dummy variables were created for: (1) the Finance and Insurance sector, (2) the Industrial and Consumer production sector, (3) the Metallic and Non-metallic Mineral Production sector, (4) the Oil, Gas and Chemicals sector, and (5) the Transportation, Warehousing and Retail Trade sector. The base sector is the Food and Agro-business sector. In the analysis that follows, the introduction of all the sectoral dummy variables looks at the effects of each sector as compared to the base sector. But after looking at alternative specifications, the only significant specification was the one that contained the Finance and Insurance (F\&I) Dummy, which compares the quality of MBAs from F\&I firms with firms in all other sectors.

The firm-level hiring requirements were also put into dummy variables. First, a dummy variable was created for firms that hired MBAs with specific skills as compared to firms that hire MBAs with general management skills. Also, two more dummy variables were created, for firms which hired MBAs with finance skills and firms that hired MBAs with marketing skills. This was done because finance and marketing skills were the two most required specific skills from graduating MBAs from firms in developing countries, according to the survey responses.

\section{Estimation Technique}

The dependent variables in the three regressions that analyzed specific MBA characteristics (technical skills, communication skills, and language skills) were limited dependent variables based on the scale: (i) Lacking, (ii) Inadequate, (iii) Adequate, and (iv) Good. The dependent variable in the regression looking at the overall quality of MBA graduates was also a limited dependent variable that followed the scale: Inadequately prepared, (ii) Fairly well prepared, (iii) Well prepared. 
An ordered logit estimation technique was used in the following analysis to examine what factors determined the quality of developing country MBA graduates. Four points should be noted. First, there are four separate econometric analyses based on the technical skills, communication skills, language skills, and overall strength of local MBA students. Second, the significance of the coefficients is based on z-statistics (rather than the usual t-statistics) because of the ordered logit estimation procedure. Third, any numerical interpretation of the coefficients is difficult due to the nature of the regression analysis. Finally, to determine the 'goodness of fit' the results include chi-squared values (based upon the likelihood ratio), since a maximum likelihood estimation procedure is being used.

\section{Analysis of the Technical Skills of Local MBA Students}

The MBA survey asked firms to rank the technical skills of local MBA graduates (discussed in Section IV). The purpose of the econometric analysis is to see what firmspecific and country factors can be isolated in terms of their effect on firm ratings of technical skills.

The results of the ordered logit regression are given in Table 6. The first thing to note is that all of the firm-specific variables are found to be insignificant in the analysis. Thus firm size, sector, skill requirements and number of MBAs hired yearly do not seem to affect the rating of local MBA technical skills.

On the other hand, the country-specific and region-specific variables do influence the technical skills rating. As the table shows, three regions have significantly lower ratings for MBAs in the area of technical skills: Africa, the Middle East, and South Asia. But GDP per capita was not found to be a significant factor in determining the technical skills of local MBAs, nor was the number of business students in the country (as a proportion of population).

These results are in keeping with the previous analysis, in which the only significant factor in the analysis of the technical skills of local MBA graduates was the regional location of the firms and the schools which produced these MBAs. 


\section{Table 6: Technical Skills of Local MBA Graduates in Developing Countries}

Dependent Variable: Quality of Technical Skills of Local MBA Graduates

(Numbers in brackets are $z$-statistics)

\begin{tabular}{|c|c|c|c|c|}
\hline Variable & & & & \\
\hline Size of Firm (No. of Employees) & $\begin{array}{l}0.00007 \\
(1.09)\end{array}$ & $\begin{array}{l}0.00008 \\
(1.18)\end{array}$ & $\begin{array}{l}0.00009 \\
(1.26)\end{array}$ & $\begin{array}{l}0.00009 \\
(1.30)\end{array}$ \\
\hline $\begin{array}{l}\text { Number of MBAs Hired by Firm } \\
\text { Yearly }\end{array}$ & $\begin{array}{l}0.105 \\
(0.62)\end{array}$ & $\begin{array}{l}0.0468 \\
(0.26)\end{array}$ & $\begin{array}{l}0.037 \\
(0.21)\end{array}$ & $\begin{array}{l}0.058 \\
(0.34)\end{array}$ \\
\hline GDP per capita in Country & $\begin{array}{l}-0.00001 \\
(-0.13)\end{array}$ & $\begin{array}{l}-0.00012 \\
(-1.25)\end{array}$ & & \\
\hline $\begin{array}{l}\text { No. of Commercial \& Business } \\
\text { Administration Students in } \\
\text { Country (all levels and both male } \\
\& \text { female) }\end{array}$ & $\begin{array}{l}114.20 \\
(1.22)\end{array}$ & $\begin{array}{l}83.24 \\
(0.70)\end{array}$ & $\begin{array}{l}64.63 \\
(0.57)\end{array}$ & \\
\hline $\begin{array}{l}\text { Finance \& Insurance Sector } \\
\text { Dummy }\end{array}$ & & $\begin{array}{l}0.342 \\
(1.05)\end{array}$ & $\begin{array}{l}0.282 \\
(0.87)\end{array}$ & $\begin{array}{l}0.38 \\
(1.24)\end{array}$ \\
\hline African Regional Dummy & & $\begin{array}{l}-1.11 * \\
(-2.08)\end{array}$ & $\begin{array}{l}-0.86 * * \\
(-1.65)\end{array}$ & $\begin{array}{l}-0.95 * \\
(-1.93)\end{array}$ \\
\hline East Asian Regional Dummy & & $\begin{array}{l}-0.44 \\
(-0.80)\end{array}$ & $\begin{array}{l}-0.34 \\
(-0.62)\end{array}$ & $\begin{array}{l}-0.613 \\
(-1.18)\end{array}$ \\
\hline Latin American Regional Dummy & & $\begin{array}{l}0.104 \\
(0.22)\end{array}$ & $\begin{array}{l}0.067 \\
(0.14)\end{array}$ & $\begin{array}{l}0.197 \\
(0.49)\end{array}$ \\
\hline Middle Eastern Regional Dummy & & $\begin{array}{l}-1.15 * \\
(-1.96)\end{array}$ & $\begin{array}{l}-0.97 * * \\
(-1.68) \\
\end{array}$ & $\begin{array}{l}-1.14 * \\
(-2.28)\end{array}$ \\
\hline South Asian Regional Dummy & & $\begin{array}{l}-1.28 * \\
(-2.12)\end{array}$ & $\begin{array}{l}-1.04 * * \\
(-1.77)\end{array}$ & $\begin{array}{l}-1.46 * \\
(-2.42)\end{array}$ \\
\hline $\begin{array}{l}\text { Dummy for Firm Hiring MBAs } \\
\text { with Specific Skills }\end{array}$ & & $\begin{array}{l}-0.263 \\
(-0.87)\end{array}$ & & $\begin{array}{l}0.383 \\
(0.64)\end{array}$ \\
\hline $\begin{array}{l}\text { Dummy for Firm Hiring MBAs } \\
\text { with Finance Skills }\end{array}$ & & & $\begin{array}{l}-0.016 \\
(-0.05)\end{array}$ & \\
\hline $\begin{array}{l}\text { Dummy for Firm Hiring MBAs } \\
\text { with Marketing Skills }\end{array}$ & & & $\begin{array}{l}0.324 \\
(0.53)\end{array}$ & \\
\hline Log of Population & & & & $\begin{array}{l}\text { 0.000013 ** } \\
(1.73)\end{array}$ \\
\hline Number of Observations & 177 & 177 & 178 & 191 \\
\hline Likelihood Ratio chi-squared & 5.21 & 15.98 & 12.98 & $20.41 *$ \\
\hline
\end{tabular}

* Significant at the 5\% level

** Significant at the $10 \%$ level. 


\section{E. Communication Skills of Local MBA Students}

Table 7 shows the results for the analysis of the communication skills of local MBAs. Once again, the firm-level variables are not significant in terms of their effect on the rating of communication skills of local MBA students in developing countries, though the number of MBAs hired by a firm on a yearly basis is weakly significant (at the $15 \%$ significance level).

As in the previous analysis, it is the regional dummy variables that stand out in terms of their effects. Interestingly, the East Asian dummy, the Latin American dummy, and the Middle Eastern dummy variables are negative and significant in this analysis. This result shows that these three regions have significant problems in terms of training their local MBA graduates to meet the communication skills requirements of local businesses.

\section{F. Language Skills of Local MBA Students}

Table 8 presents the results of the analysis of language skills of locally trained MBAs. Once again, the firm-level characteristics, such as firm size, sector, skill requirements and number of MBAs hired yearly, are found to have no significant effect on the rating of language skills of local MBA students in developing countries.

At the country level, the number of commercial and business students in the country has a significant impact on the language skills of local MBA students. Thus countries which have more business students produce MBA graduates with stronger language skills (though it should again be noted that 'stronger' means that these students have communication skills that better meet the needs of local businesses). Also, at the regional level, two regions stand out: Firms from both the Latin American region and the Middle Eastern region rate the language skills of local MBA students as inferior compared with the ratings found in the other regions. 


\section{Table 7: Communication Skills of Local Graduates in Developing Countries}

Dependent Variable: Quality of Communication Skills of Local MBA Graduates (Numbers in brackets are z-statistics)

\begin{tabular}{|c|c|c|c|c|}
\hline Variable & & & & \\
\hline Size of Firm (No. of Employees) & $\begin{array}{l}-0.0000242 \\
(-0.37)\end{array}$ & $\begin{array}{l}-0.000012 \\
(-0.18)\end{array}$ & $\begin{array}{l}-0.00002 \\
(-0.03)\end{array}$ & $\begin{array}{l}-0.00007 \\
(-0.10)\end{array}$ \\
\hline $\begin{array}{l}\text { Number of MBAs Hired by Firm } \\
\text { Yearly }\end{array}$ & $\begin{array}{l}0.311 * * \\
(1.76)\end{array}$ & $\begin{array}{l}0.262 \\
(1.42)\end{array}$ & $\begin{array}{l}0.266 \\
(1.45)\end{array}$ & $\begin{array}{l}0.25 \\
(1.46)\end{array}$ \\
\hline GDP per capita in Country & $\begin{array}{l}0.0001 \\
(1.17)\end{array}$ & $\begin{array}{l}0.00011 \\
(1.16)\end{array}$ & & \\
\hline $\begin{array}{l}\text { No. of Commercial \& Business } \\
\text { Administration Students in } \\
\text { Country (all levels and both male } \\
\& \text { female) }\end{array}$ & $\begin{array}{l}79.48 \\
(0.83)\end{array}$ & $\begin{array}{l}167.2 \\
(1.45)\end{array}$ & $\begin{array}{l}222.87 * * \\
(1.88)\end{array}$ & $\begin{array}{l}218.12 * * \\
(1.85)\end{array}$ \\
\hline $\begin{array}{l}\text { Finance \& Insurance Sector } \\
\text { Dummy }\end{array}$ & $\begin{array}{l}0.318 \\
(-0.08)\end{array}$ & $\begin{array}{l}-0.111 \\
(-0.33)\end{array}$ & $\begin{array}{l}-0.07 \\
(-0.20)\end{array}$ & $\begin{array}{l}-0.073 \\
(-0.22)\end{array}$ \\
\hline African Regional Dummy & & $\begin{array}{l}-0.223 \\
(-0.42)\end{array}$ & $\begin{array}{l}-0.248 \\
(-0.48)\end{array}$ & $\begin{array}{l}-0.274 \\
(-0.53)\end{array}$ \\
\hline East Asian Regional Dummy & & $\begin{array}{l}-1.40 * \\
(-2.52)\end{array}$ & $\begin{array}{l}-1.49 * \\
(-2.72)\end{array}$ & $\begin{array}{l}-1.49 * \\
(-2.72)\end{array}$ \\
\hline Latin American Regional Dummy & & $\begin{array}{l}-1.31 * \\
(-2.64)\end{array}$ & $\begin{array}{l}-1.24 * \\
(-2.53)\end{array}$ & $\begin{array}{l}-1.22 * \\
(-2.49)\end{array}$ \\
\hline Middle Eastern Regional Dummy & & $\begin{array}{l}-1.64 * \\
(-2.55)\end{array}$ & $\begin{array}{l}-1.75 * \\
(-2.72)\end{array}$ & $\begin{array}{l}-1.73 * \\
(-2.71)\end{array}$ \\
\hline South Asian Regional Dummy & & $\begin{array}{l}0.079 \\
(0.13)\end{array}$ & $\begin{array}{l}-0.0006 \\
(-0.001)\end{array}$ & $\begin{array}{l}-0.44 \\
(-0.07)\end{array}$ \\
\hline $\begin{array}{l}\text { Dummy for Firm Hiring MBAs } \\
\text { with Specific Skills }\end{array}$ & & $\begin{array}{l}-0.40 \\
(-1.30)\end{array}$ & & $\begin{array}{l}-0.388 \\
(-1.30)\end{array}$ \\
\hline $\begin{array}{l}\text { Dummy for Firm Hiring MBAs } \\
\text { with Finance Skills }\end{array}$ & & & $\begin{array}{l}-0.149 \\
(-0.47)\end{array}$ & \\
\hline $\begin{array}{l}\text { Dummy for Firm Hiring MBAs } \\
\text { with Marketing Skills }\end{array}$ & & & $\begin{array}{l}-0.351 \\
(-0.52)\end{array}$ & \\
\hline Number of Observations & 173 & 173 & 174 & 174 \\
\hline Likelihood Ratio chi-squared & 8.4 & $19.38 * *$ & 16.76 & $17.97 * *$ \\
\hline
\end{tabular}

* Significant at the 5\% level

** Significant at the $10 \%$ level 


\section{Table 8: Language Skills of Local MBA Graduates in Developing Countries}

Dependent Variable: Quality of Language Skills of Local MBA Graduates

(Numbers in brackets are $z$-statistics)

\begin{tabular}{|c|c|c|c|}
\hline Variable & & & \\
\hline Size of Firm (No. of Employees) & $\begin{array}{l}-0.00006 \\
(-1.02)\end{array}$ & $\begin{array}{l}-0.00006 \\
(-0.90)\end{array}$ & $\begin{array}{l}-0.00005 \\
(-0.76)\end{array}$ \\
\hline $\begin{array}{l}\text { Number of MBAs Hired by Firm } \\
\text { Yearly }\end{array}$ & $\begin{array}{l}-0.14 \\
(0.80)\end{array}$ & $\begin{array}{l}0.061 \\
(0.34)\end{array}$ & $\begin{array}{l}0.053 \\
(0.30)\end{array}$ \\
\hline GDP per capita in Country & $\begin{array}{l}-0.0001737 * \\
(-2.04)\end{array}$ & $\begin{array}{l}-0.0001181 \\
(-1.50)\end{array}$ & \\
\hline $\begin{array}{l}\text { No. of Commercial \& Business } \\
\text { Administration Students in } \\
\text { Country (all levels and both male } \\
\& \text { female) }\end{array}$ & $\begin{array}{l}120.36 \\
(1.13)\end{array}$ & $\begin{array}{l}308.1 * \\
(2.46)\end{array}$ & $\begin{array}{l}290.64 * \\
(2.42)\end{array}$ \\
\hline $\begin{array}{l}\text { Finance \& Insurance Sector } \\
\text { Dummy }\end{array}$ & $\begin{array}{l}0.19 \\
(0.61)\end{array}$ & $\begin{array}{l}0.087 \\
(0.27)\end{array}$ & $\begin{array}{l}0.047 \\
(0.15)\end{array}$ \\
\hline African Regional Dummy & & $\begin{array}{l}0.21 \\
(0.39)\end{array}$ & $\begin{array}{l}0.44 \\
(0.84)\end{array}$ \\
\hline East Asian Regional Dummy & & $\begin{array}{l}-1.68 * \\
(-2.94)\end{array}$ & $\begin{array}{l}-1.57 * \\
(-2.77)\end{array}$ \\
\hline Latin American Regional Dummy & & $\begin{array}{l}-1.52 * \\
(-3.09)\end{array}$ & $\begin{array}{l}-1.54 * \\
(-3.15)\end{array}$ \\
\hline Middle Eastern Regional Dummy & & $\begin{array}{l}-0.76 \\
(-1.28)\end{array}$ & $\begin{array}{l}-0.62 \\
(-1.07)\end{array}$ \\
\hline South Asian Regional Dummy & & $\begin{array}{l}0.68 \\
(1.15)\end{array}$ & $\begin{array}{l}0.87 \\
(1.50)\end{array}$ \\
\hline $\begin{array}{l}\text { Dummy for Firm Hiring MBAs } \\
\text { with Specific Skills }\end{array}$ & $\begin{array}{l}-0.42 \\
(-1.42)\end{array}$ & $\begin{array}{l}-0.37 \\
(-1.20)\end{array}$ & \\
\hline $\begin{array}{l}\text { Dummy for Firm Hiring MBAs } \\
\text { with Finance Skills }\end{array}$ & & & $\begin{array}{l}-0.07 \\
(-0.22)\end{array}$ \\
\hline $\begin{array}{l}\text { Dummy for Firm Hiring MBAs } \\
\text { with Marketing Skills }\end{array}$ & & & $\begin{array}{l}0.42 \\
(0.70)\end{array}$ \\
\hline \multicolumn{4}{|l|}{ Log of Population } \\
\hline Number of Observations & 166 & 166 & 167 \\
\hline Likelihood Ratio chi-squared & 9.71 & $27.15 *$ & $23.82 *$ \\
\hline
\end{tabular}

* Significant at the 5\% level

** Significant at the $10 \%$ level 


\section{G. Overall Rating of Local MBA Students}

The analysis of the overall rating of local MBA graduates by developing country firms is presented in Table 9. In particular, and in contrast to the earlier analysis, two firmspecific variables stand out: Firms that hired more MBAs on a yearly basis rated the quality of local MBAs higher than those firms that hired fewer MBAs yearly. Also, firms that hired MBAs with a focus on marketing rated local MBAs higher. Thus, all things being equal, it seems that MBAs with a focus on marketing are better prepared for working in developing country firms than MBAs with a focus on general management or finance. This implies that marketing may be better taught in developing country MBA programs on average than other areas of specialization.

At the country level, the number of commercial and business students in a country positively affects the rating of local MBAs by developing country firms. This finding is intuitively appealing since it implies that the greater the number of students studying business, the more competition among students for places in business schools and jobs, which drives up the overall perception of quality of MBA graduates. Also, three regions stand out for having significantly lower ratings for locally trained MBAs: the Africa region, the East Asia region and the Middle Eastern region. Firms in these regions are significantly less satisfied with the quality of locally trained MBAs than firms in other regions.

\section{H. Basic Conclusions}

The results emphasize country and regional factors over firm-specific factors. In particular, firm-specific factors such as firm size and the average number of MBA graduates hired each year seem to have little influence on the quality ratings that firms assign to locally trained MBAs. The only exception is the significantly higher rating firms that hire MBAs with marketing expertise give to local MBA graduates. All things equal, this implies that the quality of training in the area of marketing is more in tune with the needs of local businesses than other areas of training.

At the country level, the only factor that had any impact on the rating of local MBA students was the number of commercial and business graduates in the country (as a proportion of the population). The greater the number of business students in the country, the better the communication skills, language skills and overall quality of MBA students. This result makes sense because the greater the number of business students, the larger the pool of qualified candidates and the greater the competition for jobs, which should positively affect MBA training quality.

At the regional level, African firms were dissatisfied with the technical skills of locally trained MBAs, and the overall quality of local MBAs. Though the firms were not dissatisfied with the communication and language skills of these MBA graduates, local firms reported that on the whole the African MBA graduates were not meeting their needs. 
East Asian firms found that the communication, language skills, and overall quality of local MBAs were unsatisfactory, while only the technical skills were well suited to their needs. This implies a strong emphasis in East Asian MBA programs on technical and analytical skills, at the expense of communication and language skills. This weakness reduces the utility of local MBA graduates to hiring firms.

Latin American firms also found that the communication and language skills of local MBAs are insufficient, while their technical skills were satisfactory. But this weakness in communication skills was not a major problem with local MBAs, and hiring firms were satisfied with the overall quality of these graduates.

The Middle Eastern firms said that their local MBA graduates had weak technical skills, weak communication skills and were weak overall. Though the firms did find the language skills of locally trained MBAs satisfactory, the general result is that there is a significant difference in the training of MBAs being produced in the Middle East and the needs of the local firms.

Finally, South Asian firms only found weaknesses in the technical skills of local MBA graduates, but were satisfied with their communication skills, language skills and their overall skills.

An important point worth noting is that all the econometric results looking at regional differences in the quality of local MBAs used the European region as the base region. So when a region was found to be significantly weaker in a particular area, this is relative to European MBAs. Also, it is worth noting that none of the regions was found to be significantly stronger than Europe in any particular area. This implies that European firms are more satisfied with local MBA training than the other regions, and perhaps the experience of Eastern European MBA programs can be used to help match MBA training with local needs in other regions.

It is interesting to put this all together: firms in East Asia and Latin America are dissatisfied with the language and communication skills of local MBA graduates, though only the East Asian firms are also dissatisfied with local MBA graduates on the whole. On the other hand, African and South Asian firms are significantly dissatisfied with the technical skills of local MBAs (while being satisfied by the language and communication skills of local MBAs), though only African firms are dissatisfied with local MBAs on the whole. Finally, firms in the Middle East are dissatisfied with almost all aspects of local MBA training, which implies the strongest disconnect between firms and local MBA training across regions. 


\section{Table 9: Overall Rating of Local MBA Graduates in Developing Countries}

Dependent Variable: Overall Rating of Local MBA Graduates

(Numbers in brackets are $z$-statistics)

\begin{tabular}{|c|c|c|c|}
\hline Variable & & & \\
\hline Size of Firm (No. of Employees) & $\begin{array}{l}-0.00001 \\
(-0.16)\end{array}$ & $\begin{array}{l}-0.000022 \\
(-0.32)\end{array}$ & $\begin{array}{l}-0.0002 \\
(-0.31)\end{array}$ \\
\hline $\begin{array}{l}\text { Number of MBAs Hired by Firm } \\
\text { Yearly }\end{array}$ & $\begin{array}{l}0.37 * \\
(2.05)\end{array}$ & $\begin{array}{l}0.32 * * \\
(1.68)\end{array}$ & $\begin{array}{l}0.28 * * \\
(1.65)\end{array}$ \\
\hline GDP per capita in Country & $\begin{array}{l}0.00004 \\
(0.04)\end{array}$ & $\begin{array}{l}-0.00007 \\
(-0.73)\end{array}$ & \\
\hline $\begin{array}{l}\text { No. of Commercial \& Business } \\
\text { Administration Students in } \\
\text { Country (all levels and both male } \\
\text { \& female) }\end{array}$ & $\begin{array}{l}106.9 \\
(1.10)\end{array}$ & $\begin{array}{l}219.69 * * \\
(1.76)\end{array}$ & $\begin{array}{l}241.98 * \\
(1.98)\end{array}$ \\
\hline $\begin{array}{l}\text { Finance \& Insurance Sector } \\
\text { Dummy }\end{array}$ & $\begin{array}{l}-0.337 \\
(-1.04)\end{array}$ & $\begin{array}{l}-0.275 \\
(-0.82)\end{array}$ & $\begin{array}{l}-0.277 \\
(-0.82)\end{array}$ \\
\hline African Regional Dummy & & $\begin{array}{l}-1.35 * \\
(-2.36)\end{array}$ & $\begin{array}{l}-1.15 * \\
(-2.03)\end{array}$ \\
\hline East Asian Regional Dummy & & $\begin{array}{l}-1.37 * \\
(-2.43)\end{array}$ & $\begin{array}{l}-1.43 * \\
(-2.53)\end{array}$ \\
\hline Latin American Regional Dummy & & $\begin{array}{l}-0.66 \\
(-1.35)\end{array}$ & $\begin{array}{l}-0.58 \\
(-1.17)\end{array}$ \\
\hline Middle Eastern Regional Dummy & & $\begin{array}{l}-1.53 * \\
(-2.43)\end{array}$ & $\begin{array}{l}-1.44 * \\
(-2.34)\end{array}$ \\
\hline South Asian Regional Dummy & & $\begin{array}{l}-0.56 \\
(-0.93)\end{array}$ & $\begin{array}{l}-0.49 \\
(-0.82)\end{array}$ \\
\hline $\begin{array}{l}\text { Dummy for Firm Hiring MBAs } \\
\text { with Specific Skills }\end{array}$ & $\begin{array}{l}-0.46 \\
(1.45)\end{array}$ & $\begin{array}{l}0.45 \\
(.141)\end{array}$ & \\
\hline $\begin{array}{l}\text { Dummy for Firm Hiring MBAs } \\
\text { with Finance Skills }\end{array}$ & & & $\begin{array}{l}0.42 \\
(1.21\end{array}$ \\
\hline $\begin{array}{l}\text { Dummy for Firm Hiring MBAs } \\
\text { with Marketing Skills }\end{array}$ & & & $\begin{array}{l}1.70 * \\
(2.56)\end{array}$ \\
\hline \multicolumn{4}{|l|}{ Log of Population } \\
\hline Number of Observations & 170 & 170 & 171 \\
\hline Likelihood Ratio chi-squared & 7.87 & $19.12 * *$ & $23.78 *$ \\
\hline
\end{tabular}

* Significant at the $5 \%$ level

** Significant at the $10 \%$ level 


\section{Conclusions}

In recent decades the MBA degree (or equivalent) has become an international degree. Internationally, far more students are receiving graduate business degrees, and competition between business schools and business students is assumed to have driven up the standard of graduate business education. But so far this has only been assumed and almost no work has been done to determine the perceptions of managers in developing country firms about the quality of the business school graduates produced locally.

In order to get a sense of the quality of MBAs throughout the world, the IFC used its extensive contacts to conduct a survey of developing country firms. The survey only covered firms with which the IFC had contacts, which may bias the results since these firms are usually the larger, well-established firms in developing countries. But even bearing this in mind, the results from the survey were extremely revealing.

The strengths and weaknesses of developing and transition country MBAs seem to overlap with those of MBAs from the U.S.: managers in the U.S. and in the developing countries find that the technical and analytical skills of MBAs are well developed while the practical training/skills and communication/language skills of MBAs are significantly lacking. This is an important result because it shows the areas in which MBA programs worldwide need to be strengthened.

In particular, the technical skills of developing-country MBAs were found to be strong, though Africa, South Asia, and the Middle East stood out because of the inadequate technical training of local MBAs. The communication skills were also considered strong, except in the Middle East, while the language skills seem to be a major problem for the Latin American and East Asian regions.

On the whole, only the African and Middle Eastern firms were significantly dissatisfied with the quality of local MBA graduates. It is interesting to note that these two regions also stand out because a significant percentage of firms from each of these regions said that there was a lack of availability of MBA graduates. So while the other regions had problems with certain skills of local MBA graduates (South Asia's concern with analytical skills and Latin America and East Asia's concern with language skills), the two regions with the greatest shortage of MBAs were producing the weakest candidates.

The results show that MBAs worldwide are not fully satisfying the needs of firms. The Eastern European region stands out as the region in which firms are the most satisfied with different aspects of MBA training. Each of the other regions of the world has its own particular weaknesses, while at the same time some common weaknesses (such as work experience and communication skills) stand out. These results show that a 'cookie-cutter' approach to training MBAs cannot work. Rather, MBA programs have to be tailored to suit the needs of the local business community while also teaching common business fundamentals. If not, East Asian and Latin American MBAs will still lack language skills, South Asian and African MBAs will 
lack technical skills, and firms will not be getting managers of sufficient quality to meet their business needs. 


\section{References}

Deaton, A., 1997, The Analysis of Household Surveys: A Microeconomic Approach to Development Policy, Baltimore, Maryland: Johns Hopkins University Press.

Greene, W., 2000, Econometric Analysis, Upper Saddle River, N.J.: Prentice Hall.

Harris, R. and Barr, S., 1997, "Incomplete Education,” CFO Magazine, April 1, 1997.

Leonhardt, D., "A Matter of Degree? Not for Consultants," 2000, New York Times, October 1, 2000, Section 31, 1-18.

Lieber, R., 1999, "Learning and Change: Roger Martin," Fast Company, December 1999, 30: 262.

Louw, L. 1999, The Status and Nature of MBA Programmes in South Africa, University of Port Elizabeth, Port Elizabeth: Unpublished D.Com thesis.

Maddala, G.S., 1983, Limited-Dependent and Qualitative Variables in Econometrics, Cambridge: New York: Cambridge University Press.

Mintzberg, H., and Gosling J., 2002, "Reality Programming for MBAs," Strategy and Business, 26(1), 28-31.

Neelankavil, J., 1994, “Corporate America's Quest for an Ideal MBA,” Journal of Management Development, Vol. 13, No. 5, 38-52.

Pesulima, L.S., 1990, Empirical Investigation of the MBA Program in Indonesia: Academic versus Practitioner Perceptions, Nova University, Fort Lauderdale, Florida: Published PhD thesis.

Pfeffer, J. and Fong, C., 2002, "The End of Business Schools? Less Success than meets the Eye," Journal of Management Learning and Education, 2002, Vol. 1, No. $1,78-95$.

Porter, L. and McKibbin, L., 1988, Management Education and Development: Drift or Thrust into the $21^{\text {st }}$ Century, New York: McGraw Hill. 


\section{Annex A: IFC MBA Survey}

\section{MBA SURVEY}

1.Roughly, how many employees are there in your firm?

2.Approximately, how many MBAs from local business schools do you hire each year? (Please mark with an " $X$ " for your selection)

$$
\text { 1-2 3-10 More than } 10
$$

3.If none, is there any specific reason? (We would appreciate any answer to help understand why)

4.If you do hire local MBAs, which local MBA schools do you usually hire from?

EVEN IF YOU HAVE NOT HIRED ANY RECENT MBA GRADUATES FROM LOCAL BUSINESS SCHOOLS, RESPONSES TO QUESTIONS 5 -11 WOULD STILL BE APPRECIATED, IF YOU FEEL YOU CAN RESPOND

5. When you hire MBAs from local business schools, do you generally seek individuals with general management skills, or individuals with a specific area of expertise (such as Finance, Operations Management, Marketing, etc.)?: (Please mark with an " $X$ " for your selection)

$$
\text { General Management Specific Expertise (Please Specify:) }
$$

6.How would you rate the training that has been provided to the newly hired, locally educated,

MBAs: (Please mark with an " $X$ " for your selection)

$$
\text { Not Applic. Lacking Inadequate Adequate Good }
$$

A) Technical skills in addressing standard business problems

B) Interpersonal and communication skills

C) Fluency in a relevant international business language (e.g. English)

7.In your experience, what are recently hired MBAs from local business schools best at?

8. In your experience, which skills do recently hired MBAs from local business schools lack most?

9. What is your overall evaluation of local MBA programs? (Please mark with an " $X$ " for your selection)

MBAs are inadequately prepared $\quad$ MBAs are fairly well prepared $\quad$ MBAs are well prepared $\quad$ Not applicable

10. What do you consider to be the best business school in your country?

11. Do you have any additional comments or points of clarification on the above? 


\section{Annex B: IFC MBA Survey Responses (by Country)}

\begin{tabular}{|c|c|}
\hline Country & $\begin{array}{c}\text { Number of Firms } \\
\text { Responding }\end{array}$ \\
\hline Africa Region & 2 \\
\hline Albania & 2 \\
\hline Argentina & 7 \\
\hline Armenia & 1 \\
\hline Asia Region & 1 \\
\hline Azerbaijan & 1 \\
\hline Bangladesh & 1 \\
\hline Benin & 1 \\
\hline Bolivia & 1 \\
\hline Bosnia and Herzegovina & 2 \\
\hline Brazil & 14 \\
\hline Bulgaria & 4 \\
\hline Cambodia & 1 \\
\hline Chile & 2 \\
\hline China & 7 \\
\hline Colombia & 7 \\
\hline Costa Rica & 2 \\
\hline Cote D'Ivoire & 1 \\
\hline Croatia & 4 \\
\hline Czech Republic & 1 \\
\hline Dominican Republic & 2 \\
\hline $\begin{array}{l}\text { Europe and Central Asia } \\
\text { Region }\end{array}$ & 4 \\
\hline Ecuador & 1 \\
\hline Egypt & 6 \\
\hline El Salvador & 1 \\
\hline Eritrea & 1 \\
\hline Estonia & 4 \\
\hline Fiji & 1 \\
\hline Georgia & 4 \\
\hline Ghana & 1 \\
\hline Guatemala & 1 \\
\hline Honduras & 1 \\
\hline Hungary & 1 \\
\hline India & 7 \\
\hline Indonesia & 8 \\
\hline Jamaica & 1 \\
\hline Jordan & 2 \\
\hline Kazakhstan & 3 \\
\hline Kenya & 6 \\
\hline Korea, Republic of & 3 \\
\hline Kyrgyz Republic & 3 \\
\hline $\begin{array}{l}\text { Latin American \& } \\
\text { Caribbean Region }\end{array}$ & 3 \\
\hline
\end{tabular}

\begin{tabular}{|c|c|}
\hline Country & $\begin{array}{c}\text { Number of Firms } \\
\text { Responding }\end{array}$ \\
\hline Lebanon & 7 \\
\hline Liberia & 1 \\
\hline Macedonia & 5 \\
\hline Maldives & 1 \\
\hline Mauritania & 1 \\
\hline Mauritius & 1 \\
\hline Middle East \& N. Africa & 1 \\
\hline Mexico & 12 \\
\hline Moldova & 3 \\
\hline Nepal & 1 \\
\hline Nicaragua & 1 \\
\hline Nigeria & 4 \\
\hline Oman & 1 \\
\hline Pakistan & 9 \\
\hline Panama & 2 \\
\hline Peru & 7 \\
\hline Philippines & 7 \\
\hline Poland & 3 \\
\hline Romania & 6 \\
\hline Russian Federation & 4 \\
\hline Senegal & 2 \\
\hline South Africa & 4 \\
\hline Sri Lanka & 5 \\
\hline Swaziland & 1 \\
\hline Tajikistan & 1 \\
\hline Tanzania & 5 \\
\hline Thailand & 7 \\
\hline Togo & 1 \\
\hline Trinidad and Tobago & 1 \\
\hline Tunisia & 1 \\
\hline Turkey & 25 \\
\hline Uganda & 2 \\
\hline Ukraine & 1 \\
\hline Uzbekistan & 4 \\
\hline Venezuela & 3 \\
\hline Vietnam & 3 \\
\hline West Bank and Gaza & 4 \\
\hline Yemen, Republic of & 2 \\
\hline Yugoslavia, Fed. Rep. of & 2 \\
\hline Zambia & 4 \\
\hline Zimbabwe & 2 \\
\hline Total & 283 \\
\hline
\end{tabular}


